„Bohemistyka” 2020, nr 2, ISSN 1642-9893

Elżbieta SZCZEPAŃSKA

DOI: $10.14746 /$ bo. 2020.2 .8

Uniwersytet Jagielloński

\section{Na tropie czeskich i polskich ciekawostek kulinarnych}

Keywords: kulinary, etymology, dictionaries, „Spanish bird”, „Breton beans”

Słowa kluczowe: kulinaria, etymologia, słowniki, španělský ptáček, fasolka po bretońsku

\section{Abstract}

The article is a review of several Polish and Czech names of dishes whose origin we cannot always find out from known and available etymological or descriptive dictionaries. It is especially about dishes with slightly misleading names such as, e.g., Czech "Spanish bird" or Polish "Breton beans". To find out more about their origins, we need to consult the Internet and Wikipedia. The dishes described here constitute a small percentage of many older and new names of culinary delights ignored - unfortunately - by lexicographers, despite the fact that they are known and used very often by Czech and Polish language users.

Artykuł stanowi przegląd kilku polskich i czeskich nazw potraw, o których pochodzeniu nie zawsze możemy dowiedzieć się ze znanych nam i dostępnych słowników etymologicznych bądź opisowych. Chodzi zwłaszcza o potrawy o nazwach nieco mylących, takich jak np. czeski „španělský ptáček” lub polska „fasolka po bretońsku". Żeby dowiedzieć się czegoś więcej na temat ich genezy, musimy sięgnąc do Internetu oraz Wikipedii. Opisane tutaj dania stanowia niewielki procent wśród wielu starszych i nowych nazw kulinarnych przysmaków ignorowanych - niestety przez leksykografów, mimo że są one znane i wykorzystywane bardzo często przez użytkowników języka czeskiego i polskiego.

Co wspólnego ma kawa po turecku z Turcją, ryba po grecku z Grecją, a pierogi ruskie z Rosją, pytaja niektórzy dociekliwi Polacy. Czesi mogliby tutaj odpowiedzieć - to samo, co moravský vrabec z Morawami, španélský ptáček z Hiszpanią czy np. frankfurtská polévka z Frankfurtem.
Říci, za jak dlouho a za jakých podmínek se ustálí název pro jídlo, nelze. Je to velmi specifické. Někdy je to založeno na omylu, někdy je impulsem pro pojmenování náhodná událost, jindy si konkurují dva názvy,

mówi w jednym z wywiadów znany czeski etymolog z Uniwersytetu Karola, Jiří Rejzek (Holeček 2019). Może jednak dwa tak blisko spokrewnione ze sobą języki jak czeski i polski mogłyby w tej dziedzinie podpowiedzieć nam nieco więcej i uchylić rąbka niektórych kulinarnych tajemnic.

Choć nazwy potraw czasem brzmią dziwnie, z biegiem czasu wrastają w język i najczęściej nie zastanawiamy się, skąd pochodzą. Nazwy dań nie zawsze są jednak przypadkowe, ale mogą być na przykład związane z konkretnymi osobami lub okolicznościami ich powstania. I tak gulasz (czes. też segedínský guláš), który obecny jest w kuchni polskiej i czeskiej, narodził się ponoć na węgierskich pastwiskach i stamtąd też pochodzi nazwa tego dania. Jego twórcami sa pasterze, którzy od wiosny do jesieni wypasali na nizinach bydło i musieli sami sobie gotować. Pasterskie danie, które wymyślili nazwano od bydła, którym się opiekowali (gulya) oraz od samych pasterzy (gulyas). Podobno nawet Węgrzy nie są do końca pewni, czy nazwa ta ma związek z miastem Szeged (Szegedi gulyás), czy może z osobą pisarza węgierskiego Józsefa Székely, który zasłynął ponoć przyprawami użytymi w przyrządzaniu wspaniałego gulaszu (Székely gulyás; Holeček 2019).

A co na ten temat mówią słowniki etymologiczne? Właściwie prawie to samo. V. Machek (1971) podaje w swoim słowniku, że jest to potrawa węgierskiego pochodzenia (evropeismus) z węg. gulyás, utworzonego od gulya 'stado bydła'. W języku czeskim obecność $g$ W nagłosie wyrazu guláš zdradza ponadto obce pochodzenie, ponieważ zabrakło tutaj przejścia $g>h$, które w rodzimym czeskim słownictwie było bardzo konsekwentne już od XIII wieku.

Stownik etymologiczny języka polskiego (Boryś 2006) podaje podobną genezę - gulasz: 'potrawa z pokrajanego na kawałki mięsa' od XIX wieku, z węg. gulyás zamiast gulyáshús = gulyás 'pasterz bydła', gulya 'trzoda', hús 'mięso'. Ciekawe natomiast, że w języku węgier- 
skim funkcjonuje obecnie zupełnie inne określenie tej potrawy, a mianowicie pochodzące $\mathrm{z}$ języka ludowego pörkölt. Nazwa ta wywodzi się z dawnego węg. słowa pergelt, co oznacza 'przypieczony, przyrumieniony'.

Skoro jesteśmy już przy węgierskich rarytasach, rzućmy okiem na jeszcze jedno pyszne danie, którego nazwa pochodzi w czeszczyźnie także z języka węgierskiego, chociaż przyjęła się tutaj za pośrednictwem słowackiego - chodzi o znany w polszczyźnie naleśnik określany po czesku jako palačinka. Obecna receptura naleśników różni się nieco od tej znanej już w czasach starożytnej Grecji. Każda kultura, która przejmowała ten popularny przepis, modyfikowała bowiem skład i smak dania. Jednak pierwsze informacje, które opisywały ciasto podobne do dzisiejszych naleśników, pochodzą ponoć od greckiego komediopisarza Kratinosa (http1). Tworzył on w Atenach w IV wieku p.n.e., a ciasto naleśnikowe opisał w jednym ze swoich dzieł jako danie ciepłe i smaczne. Naleśniki były popularne nie tylko w Grecji, ale też w wielu innych europejskich krajach. Różnorodność wersji ciast naleśnikowych daje sporą swobodę, tak że nie jest ważne dokładne zachowywanie proporcji składników. Naleśniki możemy przyrządzić na słodko z serem. Można też dodać krem czekoladowy albo też owoce. Znane i równie popularne są też wersje z mięsem, warzywami, kapustą i grzybami. Każda kompozycja tworzy nowy smak i tym samym nowy przepis. Okazuje się jednak, że także Włosi uzurpują sobie prawa autorskie do smacznego wynalazku. Jak twierdza, danie to powstało we Florencji, skąd przywiozła je do Francji Katarzyna Medycejska, gdy poślubiła francuskiego króla. Spór o pochodzenie naleśnika jako potrawy pozostawmy na razie, a sami spróbujmy porównać pochodzenie czeskiej i polskiej nazwy tego przysmaku.

Jak podaje V. Machek (1971), palačinka przyszła do czeszczyzny ze Słowacji po roku 1900. Pochodzi z węg. palacsinta < placsinta, a to z kolei z rum. plăcintă jako romański ekwiwalent łac. placenta 'plochý koláč'. Formy z przyrostkiem -inka pochodzą jego zdaniem prawdopodobnie $\mathrm{z}$ wegeierskich dialektów. Podobne uzasadnienie nazwy znajdujemy u Šmilauera:
[...] název pokrmu palačinka sleduje stopy výpůjček v několika jazycích střední a jihovýchodní Evropy. V rakousko-bavorské němčině je slovo Palatschinke převzato z českého slova palačinka, to pochází zase z mad'arského palacsinta. Palacsinta pochází z rumunského plăcintă (zákusek, koláč), který pochází z latinského slova placenta, kde znamenalo nejen plodové lůžko, ale i plochý koláč. Slovo placenta pak vychází z řeckého $\pi \lambda \alpha \kappa v \varsigma$, které je př́ibuzné se slovanským ploský. Palačinka je také název ve většině dalších slovanských jazyků (ukrajinština, slovenština - palacinka, slovinština, bosenština, bulharština, makedonština, chorvatština, srbština). $V$ polštině se toto jídlo nazývá naleśnik, v rumunštině clătită. Ve východní Evropě je ale souběžně uživán název bliny pro místní obdobu palačinek (Šmilauer 1940, s. 285).

Czyli w polszczyźnie nie mamy w nazwie węgierskich wpływów, zachowując od XVIII wieku nazwę naleśnik z rodzimym pochodzeniem, o którym możemy dokładniej przeczytać w Stowniku etymologicznym W. Borysia (2006). Jak twierdzi autor, etymologia nazwy nie jest jednak do końca pewna. Uznaje się dwie hipotezy:

1. prasł. *nalěsъnikъ $<$ prasł. $n a+$ lěse $\rightarrow$ na kracie; por. pol. lasa $\rightarrow$ drewniana krata, plecionka z prętów; ta nazwa dotyczyła zatem ciasta pieczonego na plecionce;

2. prasł. *nalistbnikb < prasł. na + listě $\rightarrow$ na liściu; ta nazwa dotyczyła zatem ciasta pieczonego na dużym liściu (Boryś 2006, s. 349).

Możliwa jest także sytuacja istnienia i funkcjonowania w języku obu słów, które później połączono w jedno znane nam dziś jako $n a-$ leśnik.

Bardzo interesujące są zarówno w czeszczyźnie, jak i polszczyźnie nieco dziwne i jakby „obce” nazwy niektórych wyśmienitych a wspomnianych na samym wstępie dań. Próżno jednak szukać ich w słownikach czy leksykonach, ponieważ niektóre nazwy gastronomicznych specjałów nie znalazły tam jak na razie swojego miejsca. Pisze o tym z pewnym ubolewaniem badająca owo zagadnienie Jolanta Tambor, o czym niżej. Większość informacji na temat tych wynalazków kulinarnych możemy znaleźć tylko w Internecie albo Wikipedii i są one na tyle interesujące, że żal byłoby z nich rezygnować. Wystarczy prześledzić historie potrawy określanej przez Czechów jako španělský ptáček. Jakiego pochodzenia jest owa nazwa, która pozornie ma coś 
wspólnego z hiszpańską gastronomią? Szukanie jej w Hiszpanii jest tak samo bezowocne, jak dopatrywanie się pochodzenia nazwy zbójnicka pieczeń w schedzie po Janosiku. Zapewne niekiedy chodziło autorom nowych potraw, aby nadać swoim „osiągnięciom” kulinarnym atrakcyjne, a nawet czasemy egzotyczne, nazwy. Prowadziło to często do tworzenia gigantycznych oszustw etymologicznych i nazewniczych, których źródeł nikt już dzisiaj nie potrafi odnaleźć ani rozwiązać (Tambor 2015). W przypadku španělskiego ptáčka poszukiwanie genezy owej nazwy prowadzi w kilku kierunkach. Po raz pierwszy o potrawie tej wspomina ksiądz katolicki Jiř́́ Evermod Košetický w swojej książce kucharskiej, która ukazała się pod koniec XVII wieku (Holeček 2019). Nazwę taka uzyskały zawijane mięsne zraziki, a to prawdopodobnie dlatego, że przygotowywali je kucharze z Hiszpanii, którzy znaleźli się wówczas na dworze cesarza Rudolfa II dzięki jego matce, cesarzowej Marii będącej z pochodzenia Hiszpanką. Dzięki temu specjał ten zaczął pojawiać się w dworskim jadłospisie i stał się z biegiem czasu niemalże legendą. Natomiast druga część nazwy (ptáček) związana jest zapewne z podobieństwem zwiniętych płatów mięsa wraz z zawartością do niewielkich ptaszków. Ponieważ roladki cielęce kucharz spinał na obydwu końcach przy pomocy wykałaczek, mięso podczas pieczenia wybrzuszało się, przypominając wyglądem tułów małego ptaszka z nóżkami z wykałaczek. Za czasów Rudolfa II Praga była wciąż jeszcze centrum kultury nauki i sztuki i wie o tym każdy czeski uczeń. Jednak o tym, że władcy temu zawdzięczają Czesi mięsną roladkę (zrazik) z parówką, słoniną, gotowanym jajkiem i ogórkiem w środku wiedzą tylko nieliczni. W następnym stuleciu np. Magdalena Dobromila Rettigová ${ }^{1}$ nazwą španělský ptáček określała już nieco inną potrawę, bo roladkę wykonaną z liścia kapusty wypełnionego wieprzowym farszem (http19). Później taką samą nazwą

1 Magdalena Dobromila Rettigová (1785-1845), czeska pisarka i kucharka, autorka książki kucharskiej Domáci kuchařka aneb Pojednání o masitých pokrmech pro dcerky české a moravské (1826), dzieła fundamentalnego w gastronomil czeskiej, oraz Kafičko a vše, co je sladkého (1843) (por.https://pl.wikipedia.org/ wiki/Magdalena_Dobromila_Rettigová). określało się roladkę z cielęciny wypełnioną farszem z sardeli (anchois) z bułką. Podobną wersję podaje Nová česká Kuchařka z roku 1869 Františki Hansgirgovej (http6). Na przełomie XIX i XX wieku pojawiła się zmodyfikowana nieco wersja tej potrawy, gdzie farsz stanowi mieszanina masła, sardeli, cebuli oraz bułki bądź jest to farsz mięsny z trzech rodzajów mielonego mięsa połączonych z jajkiem. Według takiego przepisu przygotowuje potrawę np. Oldřich Sahajdák, znany współcześnie w Czechach mistrz kuchni, wykonując doń sos z dodatkiem korniszonów i musztardy (http20). Španělský ptáček w tej formie, jaką dziś w Czechach znamy, czyli z wołowego mięsa, pochodzi jednak z lat pięćdziesiątych ubiegłego stulecia. Oryginalny španělský ptáček nie pojawia się już dzisiaj zbyt często w jadłospisie czeskich restauracji. Smaczne danie ustąpiło miejsca innym kuchniom - włoskiej, greckiej bądź azjatyckiej... a szkoda.

Jak zatem dochodzi do powstawania tego typu nazw, których nie brakuje też na polskim gruncie ,kulinarno-językowym”? Tematyce kuchni w języku i kulturze poświęcona była konferencja naukowa, zorganizowana w Instytucie Języka Polskiego im. Ireny Bajerowej Uniwersytetu Śląskiego w Katowicach w 2017 w roku. Prelegenci zastanawiali się tam m.in. nad genezą nazw, które sygnalizują, że kuchnia polska jest nie do końca polska albo że przynajmniej są w niej obecne obce wpływy. W trakcie dyskusji okazało się, że polskie dania pełne są obcych smaków i tradycji, powstawały bowiem w wyniku zderzania i mieszania się kultur, co odbiło się także na nazwach niektórych z nich - mamy u nas przecież takie potrawy, jak: kurczak po chińsku, ryba po grecku, śledź po japońsku, ruskie pierogi, fasolka po bretońsku, placek po węgiersku, kawa po turecku czy barszcz ukraiński. Przekonujące wydaje się stwierdzenie Jolanty Tambor, będącej uczestniczką wspomnianej konferencji, która stwierdziła:

To nazwy, które wyróżniają polską kulturę kulinarną, pokazując nasze wyobrażenia o krajach, które są w tych nazwach przywołane, a jednocześnie ucieleśniają nasze polskie gusta kulinarne, choć mogą się okazać co najmniej mylące dla mieszkańców tych krajów (Tambor 2017; http10). 
Z wypowiedzi tej wynika ponadto, że takie potrawy, jak np. kurczak po chińsku, nie jest serwowany w chińskich restauracjach, a nawet nikt takiej potrawy w Chinach nie je. Nazwa ta świadczy raczej o polskich w y ob ra że n i a ch o tamtejszej kuchni, ale jednocześnie odpowiada raczej p o $1 \mathrm{~s} \mathrm{k} \mathrm{i} \mathrm{m} \mathrm{gustom} \mathrm{kulinarnym.} \mathrm{W} \mathrm{rzeczywis-}$ tości chodzi tutaj bowiem o kurczaka pokrojonego w paski lub kostkę, z dodatkiem warzyw i przypraw uważanych za azjatyckie (wcale nie chińskie), ewentualnie $\mathrm{z}$ dodatkiem pędów bambusa lub grzybów (także niekoniecznie chińskich). Jednak nie zawsze tak jest. Inna jest bowiem sytuacja np. w przypadku barszczu ukraińskiego, ponieważ danie to znane jest i serwowane zarówno na Ukrainie jak i w Polsce. Jednak wersja przyrządzana w Polsce różni się od oryginału - chociaż robiona na wzór ukraińskiej zawiera w swoim składzie fasolę, której nie dodaje się na Ukrainie (Tambor 2017). Historia tej najpopularniejszej wśród potraw galicyjskich zupy sięga odległych czasów, bo XVI wieku (http12). Ponoć pierwotnie przygotowywano ją z ziela porastającego łąki a zwanego barszczem i zakwaszano kwasem z ryżowej mąki. Była to więc zupa przyrządzana na bazie aromatycznych liści ziela barszczowego. Po rozpowszechnieniu się uprawy buraków, to ich właśnie zaczęto używać do przygotowania potrawy, wskutek czego zmienił się jej kolor z zielnego na buraczany, ale nazwa pozostała bez zmian. Takie oryginalne smaki pierwotnej wersji dania odnaleźć mogą miłośnicy barszczu i kuchni ukraińskiej na Podolu w miejscowości Borszczów. Jest to nieformalna stolica barszczu, gdzie co roku odbywa się festiwal smaków kuchni ukraińskiej. Sposób sporządzania staropolskiej polewki z buraków jest zupełnie inny, mimo że nazwa jest identyczna. Przede wszystkim oryginalna wersja zza wschodniej naszej granicy nie zawiera w składzie fasoli, jak już wspomniano. Esencjonalną bazą polskiej potrawy jest połączenie m.in. smaku buraków ćwikłowych, bulionu wołowego, przecieru pomidorowego, octu, czosnku i liścia laurowego. Kluczem do sukcesu jest dodanie wszystkich składników w odpowiednim czasie tak, aby żaden z nich nie był rozgotowany i nie utracił aromatu. Warto także pamiętać, że barszcz taki podaje się odgrzewany i to nie krócej, niż godzinę po ugo- towaniu a proces gotowania jest czasochłonny i wymaga uwagi, aby w efekcie dostarczyć degustatorom niezapomnianych wrażeń smakowych.

Skoro jesteśmy już przy zupach, przyjrzyjmy się dla odmiany jednej z czeskich bardzo popularnych zup o nazwie frankfurtská polévka. Czy ma ona coś wspólnego z Frankfurtem? We Frankfurcie nad Menem w XV wieku nie gotowano wprawdzie takiej zupy, ale za to wędzono parówki i to nie byle jakie, ale ... najsłynniejsze w świecie (Datinská 2019). Według kronikarza Achillesa Augusta Lersnera wspomniane tutaj parówki sprzedawano we Frankfurcie już w roku 1487. Pierwszy obowiązujący przepis na nie pochodzący z XVIII wieku zalecał ich produkcje tylko i wyłącznie $\mathrm{z}$ chudego mięsa $\mathrm{z}$ boku nazywanego brato - stąd też ich nazwa niemiecka bratwurst. Około stu lat później powstała w pobliżu Frankfurtu wytwórnia owych parówek, które przeznaczone były już także na eksport. Jak podaje jeden z czeskich wędliniarzy, František Kšána,

Naše země byla vždycky propojená s Německem nebo Rakouskem, později Rakouskem-Uherskem, a tak není divu, že k nám většina uzenin přišla právě z těchto zemí. At' už to byl gothaj, tlačenka nebo uherák. Jediné opravdu české uzeniny jsou pražská šunka a turistický salám (Datinska 2019).

A zatem słynne parówki z Frankfurtu pojawiły się na czeskim gruncie dość wcześnie, zaczął je przyrządzać po powrocie z Frankfurtu do Wiednia znany Johann Georg Lahner ${ }^{2}$ już jako ,wiedeńskie”. I tak jedna $\mathrm{z}$ najbardziej ulubionych czeskich zup, w której pływały zgodnie $\mathrm{z}$ dawną recepturą sporządzone parówki, otrzymała nazwę frankfurtská polévka, która to nazwa $\mathrm{z}$ powodzeniem funkcjonuje do dziś. A skoro mowa o wędlinach, można by jeszcze słów kilka powiedzieć o innym czeskim przysmaku o trochę „obcej” nazwie - chodzi o wspomniany już tutaj gothaj < gothajský salám, czyli kiełbasę, z której słynie dzisiaj czeskie południowo-morawskie miasto Tišnov.

${ }^{2}$ Johann Georg Lahner (1772-1845) jest uważany za wynalazce kiełbas wiedeńskich, które sam określał frankfurter i sprzedawał je w sklepie mięsnym. Rzemieślnik ten był też założycielem rodzinnego biznesu w stolicy Austrii. 
Nie znaczy to, że genezy tego rarytasu należy właśnie tutaj poszukiwać, ponieważ pochodzi on z niemieckiego miasta Gotha-dziś jest to powiatowe miasto w Turyngii (http13). Oto co na temat procesu produkcyjnego mówi Ladislav Steinhauser, założyciel firmy, która produkuje gothaj według receptury z 1977 roku.

Jeho výrobu umožnily nové stroje na konci devatenáctého století. Zvládne ho jen ten, kdo má výkonné uzenářské stroje. Kdepak doma v kuchyni (http 13).

Zaczyna się jego przygotowanie od delikatnie posiekanego chudego mięsa wołowego zmieszanego z przyprawami w odpowiednich proporcjach. Aby mieszanka nie była zbyt gęsta i twarda, należy dodać mięso wieprzowe, dobrej jakości sadło i tłuste podgardle. Na powierzchni kiełbasy powinny być widoczne oczka thuszczu. Na smak zdecydowanie wpływają przyprawy, takie jak papryka, czarny pieprz, czosnek oraz muszkat. Praca masarzy nad przygotowaniem specjału trwa 3-4 godziny, następnie należy odczekać aż wszystko wystygnie i dopiero później przystąpić do dalszych czynności. Do sprzedaży produkt dostaje się mniej więcej po upływie 48 godzin od momentu rozpoczęcia procesu produkcyjnego. Gothajský salám spożywany jest podobnie jak tradycyjny czeski špekáček (czyli serdelek) ze słoniną. Niektórzy konsumenci wolą go na zimno z chlebem, inni na gorąco z patelni...

Z kolei kilka informacji dotyczących dwóch polskich dań o „zagranicznie" brzmiącej nazwie. Zacznijmy może od fasolki po bretońs$k u$, która znana jest chyba każdej polskiej pani domu i jak możemy się domyślić niewiele ma wspólnego z Bretanią. Sama nazwa pochodzi być może od określenia a la bretonne, czyli po bretońsku, które w kuchni francuskiej oznacza danie z użyciem fasoli coco de Paimpol, a która wyglądem łudząco przypomina naszą polską fasole - Jaśka. Jaka jest zatem historia potrawy?... Okazuje się, że może mieć ona związki z kuchnią brytyjska. W zamierzchłych czasach, bo przed okupacją rzymską, mieszkańców Wielkiej Brytanii nazywano Britonami (http5, http17, http3). Stąd bierze się przypuszczenie, że przepis na fasolę pochodzący z Wysp Brytyjskich prawdopodobnie nazywano po- czątkowo fasolka po britońsku. Z czasem Brytyjczyków przestano nazywać Britonami i zapomniano, skąd pochodzi receptura i dlatego nazwa potrawy zaczęła się kojarzyć z francuską Bretanią. Nazwę zmieniono lub po prostu przekręcono, a britoński specjał stał się $f a-$ solka po bretońsku. Nie wiadomo, kiedy brytyjski przepis dostał się do Polski i w jaki sposób ewoluował, ale jedno jest pewne, przyjął się szybko, a fasolka zagościła na naszych stołach na dobre. $Z$ kuchni francuskiej polska fasolka po bretonsku najbardziej pasuje do cassoulet. To potrawa przyrządzana w Tuluzie, która do złudzenia przypomina naszą. To gotowana biała fasola $\mathrm{z}$ dodatkiem kiełbasy, boczku, pomidorów, cebuli, przypraw i czosnku. Francuzi dokładają do niej także marchewkę i nóżki kaczki. La bretonne to we francuskiej kuchni określenie dania z fasolą, więc i ta historia pasuje do naszej nazwy, jak ulał. Być może to określenie zostało zapożyczone z Wielkiej Brytanii, a my z kolei zaczerpnęliśmy je od Francuzów? Niestety historia jedzenia nie jest - jak już wspomniano - zbyt skrupulatnie udokumentowana, więc przepis na fasolkę został opublikowany dopiero w 1855 roku jako Boston baked Bean na łamach „Frugal Housewife”.

I jeszcze słów parę o śledziu po japońsku, który podbił Polskę w czasach PRL-u. Królował głównie w barach, ale był także serwowany jako wykwintna przystawka. Skąd ta nazwa, skoro sama potrawa nie ma nic wspólnego z Japonią? Szczerze mówiąc, także tym razem... nie do końca wiadomo. Istnieją dwa wytłumaczenia, obydwa prawdopodobne. Otóż pierwsze mówi, że nazwa zainspirowana jest tym, że przekąska ta - mała, estetyczna i kolorowa - kojarzy się z japońską estetyką (http9, http7). Drugie pojawiło się w jednym z odcinków radiowej audycji „Droga przez mąkę”. Postawiono tam tezę, iż geneza nazwy związana jest z... wojną japońsko-rosyjską. Otóż śledź po japońsku podobno jest potrawą galicyjską i kiedy w roku 1904 wybuchła wspomniana wojna, mieszkańcy Galicji popierający sprawę japońską (Rosja nie cieszyła się sympatią) nazwali na cześć Japończyków popularną w tym regionie potrawę śledziem po japońs$k u$ (wypowiadał się na ten temat m.in. krakowski dziennikarz, publicysta i smakosz, nieżyjący już Olgierd Jędrzejczyk). 
Okazuje się zatem, że wcale nie tak łatwo znaleźć informacje na temat nazw niektórych potraw w słownikach etymologicznych a nawet internetowych. Dotyczy to zwłaszcza nazw potraw nowych lub takich, jak omawiane tutaj španělský ptáček, śledź po japońsku czy fasolka po bretońsku. Jak pisze Jolanta Tambor,

Nazwy obcych potraw, zwłaszcza tych najnowszych rzadko w ogóle trafiają do słowników (nawet tych internetowych), trudno np. znaleźć cokolwiek na temat spolszczonej wersji lazanii (oryg. lasagne), czy [...] nazw typu kurczak po chińsku itp. Brak nazw kulinariów w słownikach wydaje się tym bardziej dziwny, że są one przecież bardzo powszechnie i często używane a w słownikach tych znajdujemy bez problemu i w dużych ilościach szereg nazw niepowszechnych terminów, pojęć technicznych bądź naukowych, nazw obcych realiów, zwierząt, roślin, instrumentów nawet kompletnie nieznanych przeciętnemu użytkownikowi (Tambor 2015).

Wydaje się, że tego typu braki słownikowe występują też w czeskiej leksykografii i właściwie nie wiadomo dokładnie, jaka jest tego przyczyna... Mimo że wszelkiego typu programy kulinarne w polskim bądź czeskim radiu i telewizji cieszą się ostatnimi laty niezwykłą popularnością, a ludzie, tacy jak Robert Makłowicz, Ewa Wachowicz czy Karol Okrasa, są rozpoznawalni i uznawani za gwiazdy TV - nie przekłada się to na sferę lingwistyki i można chyba powiedzieć, że dają się tu nawet zauważyć wyraźne braki. Spostrzeżenia te podsumowała J. Tambor, stwierdzając:

$\mathrm{Na}$ ję z y k u zatem poświęcamy obcym kulinariom o wiele więcej uwagi niż w j e z y k u, nie notuja ich słowniki, nawet internetowe, jeśli zaś nazwa pojawia się w leksykonie, to często brak jest informacji, skąd pochodzi potrawa i jakie jest pochodzenie jej nazwy (Tambor 2015).

Trzeba zatem jedynie mieć nadzieję, że braki te zostaną w przyszłości uzupełnione. Ogólnie rzecz biorąc, można by powiedzieć, że obce realia (także te gastronomiczne) nazywane są często przy wykorzystaniu przymiotnika dookreślającego (czes. španélský ptáček czy pol. barszcz ukraiński) nawet jeśli nie jest do końca potwierdzone, czy obce pochodzenie potrawy jest takie pewne (np. ruskie pierogi lub frankfurtská polévka). Nie można ich też najczęściej odnaleźć w leksykonach, jak gdyby „kulinaria nie były realiami, które twórcy leksykonów uznawaliby za godne umieszczenia w słownikach" (Tambor 2015). Wobec sytuacji braku informacji słownikowych w słownikach tradycyjnych pozostaje dla sprawdzenia znaczeń Internet, konstatuje dalej J. Tambor, w tym także traktowana z nieufnością Wikipedia oraz ewentualnie niektóre książki kucharskie. Trudno się nie zgodzić z opinią Jolanty Tambor, że braki takie należałoby uzupełnić także w opracowaniach leksykograficznych, co - miejmy nadzieję nastąpi kiedyś.

Skróty źródel internetowych (dostęp: 23.12.2019 r.)

http1 http://beszamel.se.pl/dookola-stolu/skad-sie-wziely-nalesniki-historiakuchni,3228

http2 http://naukawpolsce.pap.pl/aktualnosci/news\%2C414112\%2Cpolskie-pot rawy-o-zagranicznej-nazwie-moga-zdziwic-mieszkancow-tych-krajow.html

http3 http://springplate.blogspot.com/2013/02/rzecz-o-nazwie-i-pochodzeniufasolka-po.html

http4 http://ugotuj.to/przepisy_kulinarne/1,87978,7240924,Krotka_historia_nalesnika.html

http5 http://www.ladyhousewife.pl/posilki/dania-glowne/miesa/pyszna-fasolkapo-bretonsku

http6 https://cs.wikipedia.org/wiki/Španělský_ptáček

http7 https://culture.pl/pl/dzielo/sledz

http8 https://e-polish.eu/blog/miedzynarodowe-aspekty-kuchni-polskiej

http9 https://gazetawroclawska.pl/sledz-po-japonsku-pierogi-ruskie-ryba-pogrecku-zjesz-je-tylko-w-polsce-przepisy/ar/c17-14484211

http10 https://londynek.net/newslajt/article?jdnews_id=17594

http11 https://pl.wikipedia.org/wiki/Gulasz

http12 https://polki.pl/przepisy/kuchnie-swiata,barszcz-ukrainski_pochodzenie, 10084560, artykul.html

http13 https://regiony.rozhlas.cz/delikatni-gothaj-pochazi-ze-saska-povest-munici-levne-suroviny-7419734

http14 https://www.forbes.cz/hezky-cesky-aneb-kde-se-vzal-talian-s-holandskym -rizkem

http15 https://www.metro.cz/kde-se-vzala-jmena-jidel-rusove-sve-vejce-neznajispanele-zase-ptacka-1ik-/praha.aspx?c=A121106_172930_metro-extra_rab

http16 https://www.ordr.cz/blog/clanek/spanelsky-ptacek-a-jine-ceske-vychytavky

http17 https://www.przyslijprzepis.pl/artykul/zagadki-kulinarne-skad-wziela-siefasolka-po-bretonsku 
http18 https://www.rodina.cz/nazor18632953.htm

http19 https://www.svet-potravin.cz/clanek/proc_,spanelsky-ptacek"

http20 https://www.tyden.cz/rubriky/apetit/co-takhle-dat-si-spanelsky-ptacek 101483.html

\section{Literatura}

B o c h n a k o w a A., 2008, Przez żoladek do serca, czyli o kilku nowszych hispanizmach kulinarnych wjęzyku polskim, „Studia Iberystyczne”, nr 7, s. 235-246.

B o r y ś W., 2006, Stownik etymologiczny języka polskiego, Kraków: Wydawnictwo Literackie.

Chru pczalsk a-Lask ow sk a A., 2013, „Jaja na trzepaku«, »Pęczak nie pęka«, „Czarna piękność«: język i styl przepisów kulinarnych Marty Gessler, „Językoznawstwo”, s. 23-32.

D a t i n s ká B., 2019, Hezky česky neb kde se vzal talián z holandským ř́zkem. Online: https://www.forbes.cz/hezky-cesky-aneb-kde-se-vzal-talian-s-holand skym-rizkem [dostęp: 23.12.2019].

H o le č e k P., 2019, Kde se vzala jména jídel? Rusové své vejce neznají. Španělé zase ptáčka. Online: https://www.metro.cz/kde-se-vzala-jmena-jidel-rusovesve-vejce-neznaji-spanele-zase-ptacka-1ik-/praha.aspx?c=A121106_172930 metro-extra rab [dostęp: 23.12.2019].

Ł o z i ń s c y M. i J., 2013, Historia polskiego smaku: kuchnia, stól, obyczaje, Warszawa: Wydawnictwo Naukowe PWN.

Łuka z u k I., 2005, Rosyjskie nazwy kulinariów na tle języków slowiańskich, Białystok: Wydawnictwo Uniwersytetu w Białymstoku.

M a c h e k V., 1945, Několik názvơ jídel, vážných i posměšných, , Naše řeč”, nr 7-8, s. $149-161$

M a c h e k V., 1971, Etymologický slovnik jazyka českého, Praha.

Now a kow sk a B., 2013, Bogactwo smaków (o nowych nazwach positków, dan i miejsc), „Poradnik Językowy”, s. 103-109.

Orłoś T. Z., 1998, Nazwy potraw i napojów pochodzenia polskiego $w$ czeskich przektadach Pana Tadeusza, [w:] Studia slawistyczne, red. Halina Mieczkowska, Julian Kornhauser, Kraków.

Orłoś T. Z., 2008, O czeskich nazwach kulinarnych, „Bohemistyka”, nr 1-4, s. 359-362.

R e j z e k J., 2001, Český etymologický slovnik, Praha.

S k ow rońs ki K. P., 2007, Amerykanizacja polskiej kultury kulinarnej: przegląd zagadnień, [w:] Pokarmy i jedzenie w kulturze: tabu, dieta, symbol, red. Katarzyna Łeńska-Bak, Opole: Uniwersytet Opolski, s. 361-381.

Š m i l a u e r V., 1940, Výklady slov: Palačinka, „Naše řeč”, nr 9-10, s. 281-288.
T a m b o r J., 2015, Egzotyzmy kulinarne w i na jezzyku Polaków. Rozważania o jedzeniu, mówieniu i pisaniu / Culinary exotics in the language and on the tongue of Polish people. Reflections on food, speaking and writing. Online: https://www.academia.edu/39537284/JOLANTA TAMBOR Culinary exo tics_in the language and on the tongue_of_Polish_people. Reflections on_food_speaking_and_writingSpotkania polonistyk trzech krajów 2015.

T a m b o r J.,2017, Czy polska kuchnia jest polska? Adaptacje obcych nazw smaków i tradycji. Online: http://naukawpolsce.pap.pl/aktualnosci/news\%2C414112 $\% 2$ Cpolskie-potrawy-o-zagranicznej-nazwie-moga-zdziwic-mieszkancow-t ych-krajow.html; także: https://e-polish.eu/blog/miedzynarodowe-aspektykuchni-polskiej. 